\title{
Biocrust effects on soil infiltrability in the Mu Us Desert: Soil hydraulic properties analysis and modeling
}

\author{
Hongjie Guan ${ }^{1,2,3^{*}}$, Xinyu Liu ${ }^{4}$ \\ ${ }^{1}$ Yanchi Research Station, School of Soil and Water Conservation, Beijing Forestry University, Beijing 100083, China. \\ ${ }^{2}$ Key Laboratory of State Forestry Administration on Soil and Water Conservation, Beijing Forestry University, Beijing 100083, China. \\ ${ }^{3}$ Beijing Engineering Research Center of Soil and Water Conservation, Beijing Forestry University, Beijing 100083, China. \\ ${ }^{4}$ State Key Laboratory of Earth Surface Processes and Resource Ecology, MOE Engineering Research Center of Desertification and \\ Blown-sand Control, Faculty of Geographical Science, Beijing Normal University, Beijing 100875, China. \\ * Corresponding author. E-mail: guanhong311@163.com
}

\begin{abstract}
The presence of biocrusts changes water infiltration in the Mu Us Desert. Knowledge of the hydraulic properties of biocrusts and parameterization of soil hydraulic properties are important to improve simulation of infiltration and soil water dynamics in vegetation-soil-water models. In this study, four treatments, including bare land with sporadic cyanobacterial biocrusts (BL), lichen-dominated biocrusts (LB), early-successional moss biocrusts (EMB), and latesuccessional moss biocrusts (LMB), were established to evaluate the effects of biocrust development on soil water infiltration in the $\mathrm{Mu}$ Us Desert, northwest of China. Moreover, a combined Wooding inverse approach was used for the estimation of soil hydraulic parameters. The results showed that infiltration rate followed the pattern BL $>$ LB $>$ EMB $>$ LMB. Moreover, the LB, EMB, and LMB treatments had significantly lower infiltration rates than the BL treatment. The saturated soil moisture $\left(\theta_{\mathrm{s}}\right)$ and shape parameter $\left(\alpha_{\mathrm{VG}}\right)$ for the EMB and LMB treatments were higher than that for the BL and LB treatments, although the difference among four treatments was insignificant. Water retention increased with biocrust development at high-pressure heads, whereas the opposite was observed at low-pressure heads. The development of biocrusts influences van Genuchten parameters, subsequently affects the water retention curve, and thereby alters available water in the biocrust layer. The findings regarding the parameterization of soil hydraulic properties have important implications for the simulation of eco-hydrological processes in dryland ecosystems.
\end{abstract}

Keywords: Cyanobacteria; Lichen; Moss; Infiltration; Inverse approach; Hydraulic parameter.

\section{INTRODUCTION}

Dryland landscape is usually characterized by woody plant patches, which is separated by open patches (Ludwig et al., 2005). The surface of these open patches is usually occupied by biocrusts (also named biological soil crusts), which result from a configuration between soil particles and cyanobacteria, algae, fungi, lichens, and mosses within the upper millimeters of the soil (Belnap, 2006; Eldridge et al., 2020; Weber et al., 2016). Biocrusts change physicochemical properties of topsoils and have a significant impact on water infiltration (Chamizo et al., 2016; Jiang et al., 2018).

A few studies have been performed to evaluate the effects of biocrusts on water infiltration. Nevertheless, contradicting results exist regarding the roles of biocrusts on soil water infiltration (Warren, 2003; Weber et al., 2016). Biocrusts modify soil infiltrability through different pathways. Biocrusts increase soil porosity, roughness and aggregate stability and improve physical structure, which in turn increase soil water infiltration (Felde et al., 2014; Jiang et al., 2018). On the other hand, biocrusts increase water repellency and cause pore clogging due to exopolysaccharide excretion, which impede soil water infiltration (Keck et al., 2016; Kidron et al., 2020; Xiao et al., 2019). These contradictory results were attributed to the difference in soil properties (soil structure and texture), biocrust characteristics (cover, morphology, and composition), and climate (mainly rainfall characteristics) (Weber et al., 2016). Therefore, further studies are necessary to test these contradicting results in other areas, such as the Mu Us Desert where the soil, climate, and biocrusts differ from other areas. In this area, a large number of shrubs died with the occurrence of latesuccessional biocrusts, possibly due to the reduced soil water infiltration caused by biocrusts (Guan and Liu, 2019; Xiao and $\mathrm{Hu}, 2017)$. However, no conclusive data are yet available and our understanding of the mechanisms of biocrusts in altering soil hydrology remains unknown.

In addition, the presence of biocrusts alters soil physical properties, and subsequently influences soil hydrological processes, and thus changes plant growth (Havrilla et al., 2019; Kidron, 2019; Xiao and Hu, 2017). Improved knowledge of the hydraulic properties of biocrusts and estimation of soil hydraulic parameters are crucial for improving simulation of infiltration, soil water dynamics, and soil water uptake in vegetationsoil-water models (Coppola et al., 2011; Wang et al., 2007; Yu et al., 2010), and have important implications for the simulation of eco-hydrological processes in dryland ecosystems (Chen et al., 2018). We hypothesized that biocrust development has a negative influence on water infiltration. Accordingly, the purposes of our study were: (1) to evaluate whether biocrust development influence soil water infiltration; (2) to estimate the hydraulic parameters in biocrust-covered soils.

\section{MATERIALS AND METHODS \\ 2.1 Experimental site}

This study was undertaken at the Yanchi Research Station, Ningxia Province, northwestern China $\left(106^{\circ} 30^{\prime}-107^{\circ} 47^{\prime} \mathrm{E}\right.$ and $37^{\circ} 04^{\prime}-38^{\circ} 10^{\prime} \mathrm{N}, 1550 \mathrm{~m}$ above the sea level). The site is lo- 
cated on the southwestern fringe of the Mu Us Desert and is characterized by a mid-temperate semi-arid climate with mean annual temperature of $8.1^{\circ} \mathrm{C}$. Mean annual precipitation in this area is $287 \mathrm{~mm}$, most of which occurs from July to September. Soil texture is classified as sand. The average sand, silt, and clay content in the shallow soil profile (0- to $10-\mathrm{cm}$ depth) are $79.1 \%, 18.5 \%$, and $2.4 \%$, respectively. The mean percentages of sand, silt and clay in lower soil (10- to 60-cm depth) are $93.0 \%, 4.3 \%$, and $2.7 \%$, respectively. The dominant shrubs are Artemisia ordosica, Caragana korshinskii, Salix psammophila, and Hedysarum mongolicum, which are distributed in patches covering $30-70 \%$ of the soil surface. The inter-canopy soil surface is commonly covered by biocrusts.

\subsection{Experimental design}

In this study, infiltration experiments were conducted in August 2017 to evaluate the influence of biocrust development on water infiltration. In this experiment, four treatments, including bare land with sporadic cyanobacterial biocrusts (BL) (Fig. 1A), lichen-dominated biocrusts (LB) (Fig. 1B), earlysuccessional moss biocrusts (EMB) (Fig. 1C), and latesuccessional moss biocrusts (LMB) (Fig. 1D), were established to evaluate the effects of biocrust development on soil water infiltration. Five replicates with similar soil and topographic conditions were established for each treatment, thus totalling 20 experimental sites.

There are three main types of biocrusts in this area: cyanobacteria, lichens, and mosses. The cyanobacterial biocrusts are consisted of Microcoleus vaginatus. The lichen-dominated biocrusts are mainly composed of Collema tenax species with a low cover of cyanobacteria. The moss-dominated biocrusts, in addition to Byumargenteum p., include a certain amount of lichens and cyanobacteria. A vernier caliper and line intercept transects were used for measuring the thickness and cover of biocrusts, respectively. Biocrust samples, which were manually screened through a $2-\mathrm{mm}$ screen and dried at $65^{\circ} \mathrm{C}$ for $24 \mathrm{~h}$, were used for measuring the biomass. The polysaccharide content of biocrust samples were also measured by the phenolsulfuric acid method. Additionally, particle size distribution of the biocrust layer and the subsurface (at 5-cm depth under biocrust layer) was determined.

\subsection{Infiltration experiments}

The infiltration experiments were performed using a disc infiltrometer with a $15 \mathrm{~cm}$-diameter disc. The height and diameter of the water reservoir tower was 100 and $3.5 \mathrm{~cm}$, respectively. In order to estimate van Genuchten parameters, three pressure heads $(h)$ of $-3,-6$, and $-12 \mathrm{~cm}$ at each infiltration point were used. Prior to each measurement, a layer of fine sand with thickness of $2 \mathrm{~mm}$ was laid on soil surface at each infiltration point and then the disc infiltrometer was put on the fine sand. The water level in the reservoir tower was recorded until it reached steady state. The time interval for observation was $10 \mathrm{~s}$ during the first $3 \mathrm{~min}$ of the infiltration experiment. However, the time interval for observation was $30 \mathrm{~s}$ when the infiltration time reached $3 \mathrm{~min}$.
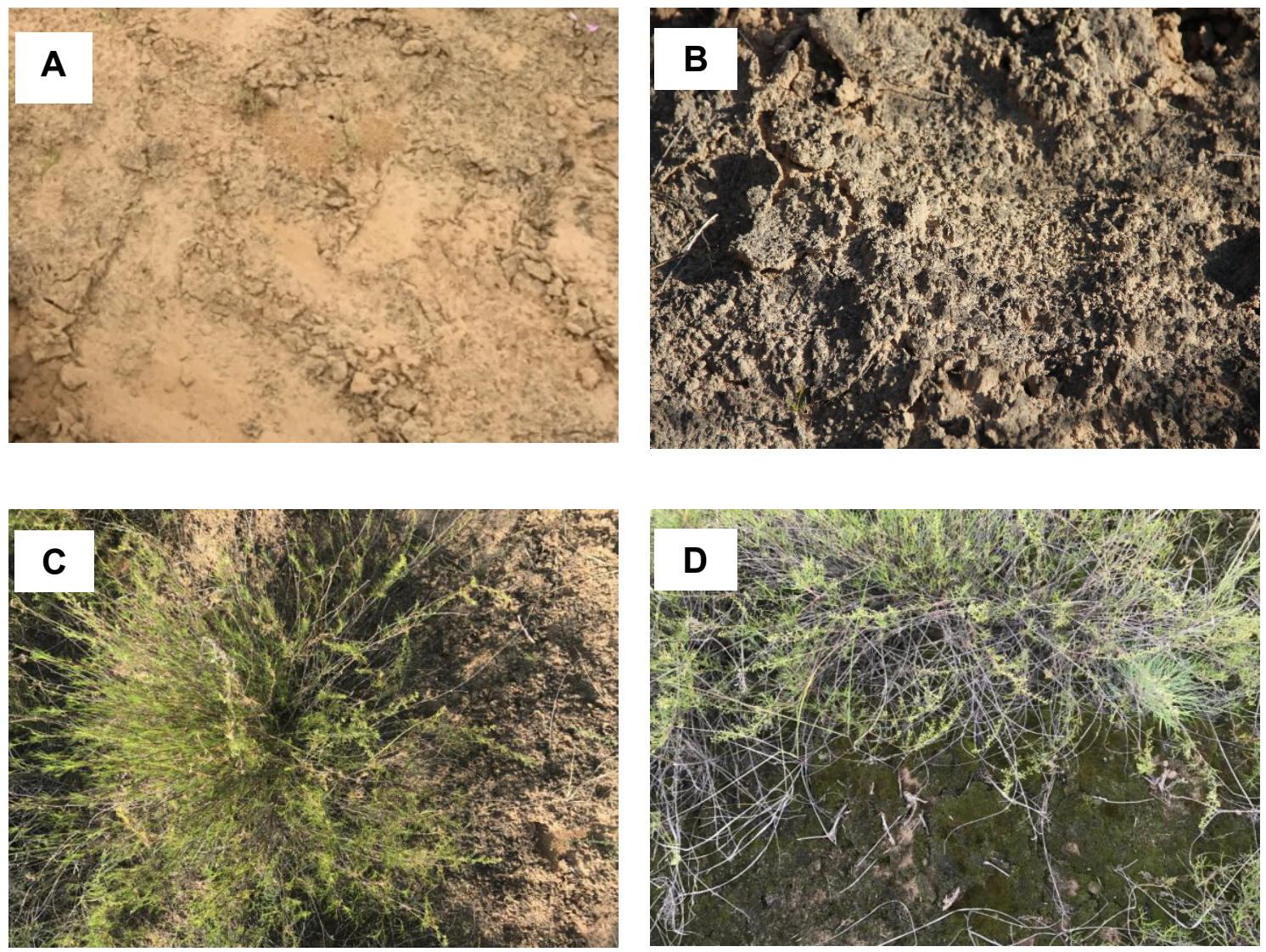

Fig. 1. Landscapes with the four treatments for study including (A) bare land with sporadic cyanobacterial biocrusts (BL), (B) lichendominated biocrusts (LB), (C) early-successional moss biocrusts (EMB), (D) late-successional moss biocrusts (LMB). 


\subsection{Calculation of soil hydraulic parameters}

The following method was adopted to analyze the infiltration data. Over time, the infiltration from a circular source with a constant pressure head can be described by the Wooding's solution (Wooding, 1968):

$$
Q=\pi r_{0}^{2} K(h)\left[1+\frac{4 \lambda_{\mathrm{c}}}{\pi r_{0}}\right]
$$

with $\lambda_{c}$ is calculated according to White and Sully (1987):

$$
\lambda_{\mathrm{c}}=\frac{b S^{2}}{\left[K(h)\left(\theta_{\text {fin }}-\theta_{\text {ini }}\right)\right]}
$$

where $r_{0}$ is the radius of the disc $(\mathrm{cm}) ; h$ is the pressure head $(\mathrm{cm})$, which was $-3,-6$, and $-12 \mathrm{~cm} ; \lambda_{\mathrm{c}}$ is the macroscopic capillary length; $K(h)$ is the unsaturated conductivity under a given pressure head $\left(\mathrm{cm} \mathrm{min}^{-1}\right) ; Q$ is the steady-state infiltration rate $\left(\mathrm{cm}^{3} \mathrm{~min}^{-1}\right) ; b$ is a shape parameter between $1 / 2$ and $\pi / 4$ (Smettem and Clothier, 1989); $\theta_{\text {fin }}$ is the final soil water content $\left(\mathrm{cm}^{3} \mathrm{~cm}^{-3}\right) ; \theta_{\text {ini }}$ is the initial surface soil water content $\left(\mathrm{cm}^{3} \mathrm{~cm}^{-3}\right)$; and $S$ is the sorptivity $\left(\mathrm{cm} \mathrm{min}^{-1 / 2}\right)$.

The $Q$ can be calculated as the following form by substituting Eq. (2) into (1):

$$
\frac{Q}{\pi r_{0}^{2}}=K(h)+\frac{4 b S^{2}}{\left[\pi r_{0}\left(\theta_{\text {fin }}-\theta_{\text {ini }}\right)\right]}
$$

with $i_{\mathrm{c}}$ is expressed as:

$i_{\mathrm{c}}=\frac{Q}{\pi r_{0}^{2}}$

From Eqs. (3) and (4), the $K(h)$ can be calculated as the following form by replacing $Q$ with constant infiltration rate $\left(i_{\mathrm{c}}\right.$, $\mathrm{cm} \mathrm{min}^{-1}$ ) (White and Sully, 1987):

$$
K(h)=i_{\mathrm{c}}-\frac{4 b S^{2}}{\left[\pi r_{0}\left(\theta_{\text {fin }}-\theta_{\text {ini }}\right)\right]}
$$

In Eq. (5), $S$ is estimated by the intercept of the regression line between $\Delta I / \Delta t^{1 / 2}$ and $t^{1 / 2}$ according to Vandervaere et al. (1997), where $\Delta t^{1 / 2}$ is the variable quantity of the square root of time ( $\mathrm{min}$ ) and $\Delta I$ is the variable quantity of cumulative infiltration $(\mathrm{cm})$; and $i_{\mathrm{c}}$ is calculated by the slope of the linear fitted cumulative infiltration curves with the stable infiltration data.

According to the quasi-linear Gardner model (Gardner, 1958), the $K(h)\left(\mathrm{cm} \mathrm{min}^{-1}\right)$ could be expressed as:

$$
K(h)=K_{\mathrm{s}} e^{\alpha_{\mathrm{GRD}}}{ }^{h}
$$

where $K_{\mathrm{s}}$ is the saturated hydraulic conductivity $\left(\mathrm{cm} \min ^{-1}\right)$; and $\alpha_{\mathrm{GRD}}$ is the exponential slope.

The $K_{\mathrm{s}}$ can be expressed using Eqs. (5) and (6).

$$
K_{\mathrm{s}} e^{\alpha_{\mathrm{GRD}}}{ }^{h}=i_{\mathrm{c}}-\frac{4 b S^{2}}{\left[\pi r_{0}\left(\theta_{\text {fin }}-\theta_{\text {ini }}\right)\right]}
$$

The $K_{\mathrm{s}}$ and $\alpha_{\mathrm{GRD}}$ in Eq. (7) are only the two unknown parameters, which could be calculated by two consecutive pressure heads. The approach assumes that parameter $\alpha_{\mathrm{GRD}}$ is constant over the interval between two consecutive pressure heads
(Coppola et al., 2011).

The microscopic pore radius $\left(\lambda_{\mathrm{m}}, \mathrm{mm}\right)$ was calculated through Eq. (8) according to White and Sully (1987).

$$
\lambda_{\mathrm{m}}=\frac{\sigma \alpha_{\mathrm{GRD}}}{\rho g}
$$

where $\sigma$ is the surface tension $\left(\mathrm{N} \mathrm{m}^{-1}\right) ; \rho$ is the density of water $\left(\mathrm{kg} \mathrm{m}^{-1}\right)$; and $g$ is the acceleration due to gravity $\left(\mathrm{N} \mathrm{kg}^{-1}\right)$.

\subsection{Estimation of van Genuchten parameters using a combined Wooding inverse approach}

Soil hydraulic properties are usually expressed by the soil hydraulic conductivity $(K(h))$ and water retention curve $(\theta(h))$. The most important work in determining the functional relationships between the soil hydraulic conductivity, water content, and matric potential is to obtain van Genuchten parameters, which are estimated using a coupled Wooding inverse approach that combined the results from Wooding's analytical solution with a parameter estimation method using a numerical solution of the Richards equation (Coppola et al., 2011; Lazarowitch et al., 2007).

The following form of the Richards equation is usually used to characterize the radially symmetric isothermal Darcian flow in a variably saturated isotropic rigid porous medium (Warrick, 1992):

$$
\frac{\partial \theta}{\partial t}=\frac{1}{r} \frac{\partial}{\partial r}\left(r K(h) \frac{\partial h}{\partial r}\right)+\frac{\partial}{\partial z}\left(K(h) \frac{\partial h}{\partial z}-1\right)
$$

where $t$ is time; $r$ is the radial coordinate; and $z$ is the vertical coordinate positive downward. Initial and boundary conditions that are appropriate for a disc tension infiltrometer experiment are expressed by the following equations (Šimůnek and van Genuchten, 2000):

$$
\begin{array}{ll}
h(r, z, t)=h_{\text {ini }}(\mathrm{z}) & t=0 \\
h(r, z, t)=h_{0}(t) & 0<r<r_{0}, z=0 \\
\frac{\partial h(r, z, t)}{\partial z}=1 & r>r_{0}, z=0 \\
h(r, z, t)=h_{\text {ini }} & r^{2}+z^{2} \rightarrow \infty
\end{array}
$$

where $h_{\text {ini }}$ is the initial pressure head $(\mathrm{cm}) ; r_{0}$ is the disc radius $(\mathrm{cm})$; and $h_{0}$ is the time-variable supply pressure head $(\mathrm{cm})$.

The van Genuchten model (van Genuchten, 1980) was chosen to express the soil water retention, $\theta(h)$, and hydraulic conductivity, $K(\theta)$ :

$$
\begin{aligned}
& S_{\mathrm{e}}=\frac{\theta-\theta_{\mathrm{r}}}{\theta_{\mathrm{s}}-\theta_{\mathrm{r}}}=\left[1+\left|\alpha_{\mathrm{VG}} h\right|^{n}\right]^{-m} \\
& m=\frac{n-1}{n} \\
& K\left(S_{\mathrm{e}}\right)=K_{\mathrm{s}} S_{\mathrm{e}}{ }^{l}\left[1-\left(1-S_{\mathrm{e}}^{1 / m}\right) m\right]^{2}
\end{aligned}
$$

where $\theta_{\mathrm{s}}$ and $\theta_{\mathrm{r}}$ are the saturated and residual soil moisture $\left(\mathrm{cm}^{3} \mathrm{~cm}^{-3}\right)$, respectively; $\alpha_{V G}\left(\mathrm{~cm}^{-1}\right), m$ and $n$ are the shape parameters; $S_{\mathrm{e}}$ is the effective fluid saturation; and $l$ is the tortu- 
osity parameter, which is usually fixed at 0.5 (Mualem, 1976).

The transient tension disc infiltration data, together with initial and final soil moisture, were used for the numerical inverse determination of van Genuchten parameters, by fixing $K_{\mathrm{s}}$ at the value obtained using Wooding's analytical solution. Given that all optimizations initially gave $\theta_{\mathrm{r}}$ estimates very close to zero, we decided to fix $\theta_{\mathrm{r}}$ to zero for all cases. The objective function, $\Phi$, for the numerical inverse approach is:

$$
\Phi(\beta)=\sum_{i=1}^{M} W_{i}\left[I_{i}^{*}\left(t_{i}\right)-I\left(\beta, t_{i}\right)\right]^{2}
$$

where $M$ is the number of measurements in a particular set; $\beta$ is the vector of optimized parameters; $W_{i}$ is the weight of a particular measured point; $I_{i}^{*}(\mathrm{~cm})$ is the measured cumulative infiltration at time $t_{i}$; and $I_{i}(\mathrm{~cm})$ is the simulated cumulative infiltration at time $t_{i}$.

Water retention curves can be obtained through the estimated van Genuchten parameters. The plant available water, which was defined as the difference in soil moisture $(\Delta \theta)$ within a pressure head ranged from -1 to $-1000 \mathrm{~cm}$, was estimated by water retention curves (Wang et al., 2007).

\subsection{Data analyses}

A two-way ANOVA was used for analyzing the effects of biocrust type and pressure head on the soil water infiltrability at the $5 \%$ probability level. The differences in soil hydraulic parameters among these treatments were analyzed using the least significant difference (LSD) tests at the $5 \%$ probability level. All statistical analyses were performed using the SPSS 19.0 software (SPSS, Chicago, IL, USA).

\section{RESULTS}

\subsection{Characteristics of biocrusts}

Generally, with the development of biocrusts, the cover, thickness, and biomass of the biocrusts significantly increased; however, the difference in biocrust cover between the EMB and LMB treatments was insignificant at the 0.05 level (Table 1). In comparison to the bare land, biocrusted soils had more silt and clay content. Moreover, higher fine content (i.e., silt and clay) was observed in the moss-covered biocrusts compared to lichen-covered biocrusts (Table 1).

\subsection{Effects of biocrust development on water infiltration}

As shown in Fig. 2, from initial to steady state, the BL treatment had significantly higher infiltration rates than the other treatments. Furthermore, infiltration rate was similar for the EMB and LMB treatments, but significantly lower than for the LB treatment. Specifically, the $i_{\mathrm{c}}$ under the pressure head of $-3 \mathrm{~cm}$ followed the pattern $\mathrm{BL}>\mathrm{LB}>\mathrm{EMB}>\mathrm{LMB}$. Furthermore, for the $\mathrm{BL}$ treatment under the pressure head of $-3 \mathrm{~cm}$, the $i_{\mathrm{c}}$ was $92.3 \%$ higher than that for the LB treatment $(P<$ 0.05 ) (Table 2). The $i_{\mathrm{c}}$ for the LB treatment under the pressure head of $-3 \mathrm{~cm}$ was $25.8 \%$ and $38.7 \%$ higher than that for the EMB and LMB treatments, although there was no significant difference in the infiltration rate among the three treatments (Table 2).

In addition, the $K(h), S, K_{\mathrm{s}}$, and $\lambda_{\mathrm{c}}$ for the BL treatment were obviously higher than that for the other treatments. In detail, the $K(h)$ and $K_{\mathrm{s}}$ for the BL treatment under the pressure head of -3 $\mathrm{cm}$ were significantly higher than that for the LB treatment by 2.0- and 2.1-fold, respectively (Table 2). Similarly, the $S$ averaged over three pressure heads followed the pattern BL $>$ LB $>$ EMB $>$ LMB. On the contrary, the $\lambda_{m}$ followed the pattern BL $<\mathrm{LB}<\mathrm{EMB}<\mathrm{LMB}$, although the difference among them was insignificant. The two-way ANOVA results indicated that the influences of biocrust type or head on $i_{\text {ini }}, i_{\mathrm{c}}, S, K(h), K_{\mathrm{s}}$, and $\lambda_{\mathrm{c}}$ were significant at the 0.01 or 0.05 level; however, the influence of biocrust type on $\lambda_{\mathrm{m}}$ was insignificant at the 0.05 level (Table 3). In addition, the influences of the interaction between the biocrust type and pressure head on $i_{\text {ini }}, i_{\mathrm{c}}, S, K(h)$, and $K_{\mathrm{s}}$ were insignificant at the 0.05 level.

\subsection{Determination of van Genuchten parameters}

As can be seen in Table 4 , the $\theta_{\mathrm{s}}$ and $\alpha_{\mathrm{VG}}$ increased with biocrust development. More specifically, the $\theta_{\mathrm{s}}$ and $\alpha_{\mathrm{VG}}$ for the EMB and LMB treatments were higher than that for the BL and LB treatments, although the difference among four treatments was insignificant. For instance, the $\theta_{\mathrm{s}}$ for the LMB treatment was $28.0 \%$ higher than that for the LB treatment. Moreover, there was no significant difference in $\theta_{\mathrm{s}}$ and $\alpha_{\mathrm{VG}}$ between the $\mathrm{BL}$ and $\mathrm{LB}$ treatments. In addition, the relation between the parameter of the $n$ and biocrust development was found to be non-unique. In detail, the BL and EMB treatments had slightly higher $n$ than the LB and LMB treatments. Furthermore, there was no obvious difference in $n$ between the BL and $\mathrm{EMB}$ treatments or between the LB and LMB treatments. The oneway ANOVA results indicated that the influences of biocrust development on $\theta_{\mathrm{s}}, \alpha_{\mathrm{VG}}$ and $n$ were insignificant at the 0.05 level (data not shown)

As shown in Fig. 3, biocrust development had a significant influence on water retention and hydraulic conductivity. Water retention increased with biocrust development at high-pressure heads, whereas the opposite was observed at low-pressure heads (Fig. 3A and B). In detail, water retention at highpressure heads followed the pattern $\mathrm{LMB}>\mathrm{EMB}>\mathrm{BL}>\mathrm{LB}$.

Table 1. Characteristics of the biocrusts in the four treatments.

\begin{tabular}{|c|c|c|c|c|c|c|c|}
\hline Treatments & $\begin{array}{c}\text { Cover } \\
(\%)\end{array}$ & $\begin{array}{c}\text { Thickness } \\
\text { (mm) }\end{array}$ & $\begin{array}{c}\text { Biomass } \\
\left(\mathrm{mg} \mathrm{cm}^{-2}\right)\end{array}$ & $\begin{array}{l}\text { Polysaccha- } \\
\text { ride content } \\
\left(\mu \mathrm{g} \mathrm{mg}^{-1}\right)\end{array}$ & $\begin{array}{c}\text { Sand } \\
(\%)\end{array}$ & $\begin{array}{l}\text { Silt } \\
(\%)\end{array}$ & $\begin{array}{l}\text { Clay } \\
(\%)\end{array}$ \\
\hline $\begin{array}{l}\text { Bare land with sporadic cyanobacterial } \\
\text { biocrusts (BL) }\end{array}$ & - & - & - & - & $85.79 \pm 5.09 \mathrm{a}$ & $12.71 \pm 1.51 \mathrm{~b}$ & $1.50 \pm 0.16 \mathrm{~b}$ \\
\hline Lichen-dominated biocrusts (LB) & $70 \pm 9.7 \mathrm{~b}^{\dagger}$ & $4.8 \pm 0.9 \mathrm{c}$ & $0.81 \pm 0.08 \mathrm{c}$ & $2.26 \pm 0.03 \mathrm{~b}$ & $84.59 \pm 4.43 \mathrm{a}$ & $13.53 \pm 2.21 \mathrm{~b}$ & $1.88 \pm 0.13 \mathrm{~b}$ \\
\hline $\begin{array}{l}\text { Early-successional moss biocrusts } \\
\text { (EMB) }\end{array}$ & $76.8 \pm 3.5 \mathrm{a}$ & $8.9 \pm 0.7 \mathrm{~b}$ & $1.84 \pm 0.36 \mathrm{~b}$ & $3.76 \pm 0.05 \mathrm{a}$ & $77.50 \pm 5.26 \mathrm{~b}$ & $20.60 \pm 2.56 \mathrm{a}$ & $1.90 \pm 0.21 \mathrm{~b}$ \\
\hline Late-successional moss biocrusts (LMB) & $95.8 \pm 1.8 \mathrm{a}$ & $15.2 \pm 0.8 \mathrm{a}$ & $2.94 \pm 0.57 \mathrm{a}$ & $3.94 \pm 0.02 \mathrm{a}$ & $75.34 \pm 4.82 \mathrm{~b}$ & $21.33 \pm 2.29 \mathrm{a}$ & $3.33 \pm 0.18 \mathrm{a}$ \\
\hline
\end{tabular}

${ }^{\dagger}$ Different letters in the same column indicate significant differences at the probability level of 0.05 . 


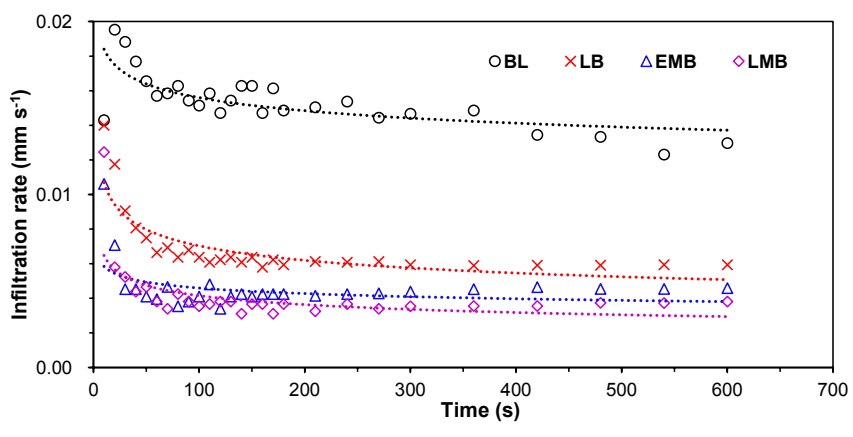

Fig. 2. Infiltration rate of the four treatments including bare land with sporadic cyanobacterial biocrusts (BL), lichen-dominated biocrusts (LB), early-successional moss biocrusts (EMB), and latesuccessional moss biocrusts (LMB).

On the contrary, Water retention at low-pressure heads followed the pattern LB $>$ BL $>$ LMB $>$ EMB. Hydraulic conductivity for the BL treatment, as shown in Fig. 3C, was obviously higher than that of the other treatments. Furthermore, there was no obvious difference among the LB, EMB, and LMB treatments, and the difference was dependent on the pressure head.

In addition, the development of biocrusts influences the water retention curve, and thus alters the available water. In detail, $\Delta \theta$ for the moss-covered treatments were obviously higher than that for the cyanobacteria- or lichen-covered treatments. For example, the available water increased from $\Delta \theta=0.251 \mathrm{~m}^{3} \mathrm{~m}^{-3}$ and $\Delta \theta=0.214 \mathrm{~m}^{3} \mathrm{~m}^{-3}$ for the $\mathrm{BL}$ and $\mathrm{LB}$ treatments to $\Delta \theta=$ $0.281 \mathrm{~m}^{3} \mathrm{~m}^{-3}$ for the EMB treatment. Moreover, for moss biocrusts, the available water increased from $\Delta \theta=0.281 \mathrm{~m}^{3} \mathrm{~m}^{-3}$ for the EMB treatment to $\Delta \theta=0.290 \mathrm{~m}^{3} \mathrm{~m}^{-3}$ for the LMB treatment. However, the available water decreased from $\Delta \theta=$ $0.251 \mathrm{~m}^{3} \mathrm{~m}^{-3}$ for the BL treatment to $\Delta \theta=0.214 \mathrm{~m}^{3} \mathrm{~m}^{-3}$ for the LB treatment (Fig. 3A and B).

\section{DISCUSSION}

\subsection{Influence of biocrust development on water infiltration}

Our study shows that the presence and development of biocrusts had a negative effect on water infiltration when com- pared to the bare land (Table 2; Fig. 2). The negative biocrust effects on water infiltration are likely due to the higher amount of clay and silt in the biocrusted soils, which could reduce soil pores and result in a decrease in water infiltration (Table 1). Additionally, the biocrust effects could attributed to the higher biocrust thickness and the polysaccharide content (Table 1). We should note that the polysaccharides measured in this study is different from exopolysaccharides (EPS), and it can only serve as a measure for biocrust biomass (similar to chlorophyll content). Namely, the polysaccharides cannot be an indication of the capacity of the biocrusts to absorb water. Although not measured in this study, the involvement of the EPS cannot be neglected. Given that the ability of the EPS to absorb copious amounts of water (Chenu, 1993; Colica et al., 2014; Mazor et al., 1996), the cyanobacterial capacity to excrete copious amounts of EPS (Kidron et al., 2003), and the fact that cyanobacteria also inhabit the lichen- and moss-dominated biocrusts (Gentili et al., 2005; Paulsrud and Lindblad, 1998; Rossi et al., 2018), an efficient impediment of infiltration is expected. This issue deserves further research.

Our results correspond to the results of other authors (Coppola et al., 2011; Xiao et al., 2019; Yang et al., 2016), who concluded that the lichen- and moss-covered biocrusts led to a decrease in water infiltration (Table 5). However, some other studies have shown the opposite: biocrusts increased water infiltration (Jiang et al., 2018; Kakeh et al., 2021) (Table 5). The difference in soil surface roughness caused by biocrusts could partly explain these contradictive results (Warren, 2003). In detail, rugose or smooth biocrusts such as cyanobacteria are common in the areas without frost-heaving, thus resulting in a low surface roughness. Nevertheless, in the areas where soils freeze, frost-heaving of biocrusted surfaces results in a highly roughened surface. Higher roughness allows more residence time, and thus leads to an increased infiltration (Warren, 2003). In this study site with no obvious frost-heaving, low surface roughness resulted in a negative effect of biocrusts on water infiltration.

Additionally, our results concluded that moss-dominated biocrusts had much lower soil infiltrability compared to the lichen-dominated biocrusts (Table 2; Fig. 2). In comparison to lichen-covered biocrusts, higher cover, thickness, biomass, and

Table 2. Soil hydraulic parameters of biocrusts and bare soil under the different biocrust development.

\begin{tabular}{|c|c|c|c|c|c|c|c|c|}
\hline $\begin{array}{l}\text { Pressure } \\
\text { head }\end{array}$ & Treatments & $i_{\text {ini }}\left(\mathrm{mm} \mathrm{min} \min ^{-1}\right)$ & $i_{\mathrm{c}}\left(\mathrm{mm} \min ^{-1}\right)$ & $K(h)\left(\mathrm{mm} \mathrm{min} \operatorname{mon}^{-1}\right)$ & $S\left(\mathrm{~mm} \mathrm{~min} \operatorname{mon}^{-1 / 2}\right)$ & $K_{\mathrm{s}}\left(\mathrm{mm} \mathrm{min} \mathrm{m}^{-1}\right)$ & $\lambda_{\mathrm{c}}(\mathrm{mm})$ & $\lambda_{\mathrm{m}}(\mathrm{mm})$ \\
\hline \multirow[t]{4}{*}{$-3 \mathrm{~cm}$} & $\mathrm{BL}$ & $1.36 \pm 0.37 \mathrm{bc}^{\dagger}$ & $0.75 \pm 0.09 \mathrm{a}$ & $0.79 \pm 0.10 \mathrm{a}$ & $0.89 \pm 0.48 \mathrm{ab}$ & $1.44 \pm 0.18 \mathrm{~b}$ & $4.87 \pm 3.27 \mathrm{bc}$ & $21.79 \pm 13.05 \mathrm{~b}$ \\
\hline & LB & $1.00 \pm 0.28 \mathrm{bc}$ & $0.39 \pm 0.06 \mathrm{~b}$ & $0.39 \pm 0.06 \mathrm{~b}$ & $0.18 \pm 0.06 \mathrm{~b}$ & $0.70 \pm 0.11 \mathrm{c}$ & $0.54 \pm 0.24 \mathrm{c}$ & $453.81 \pm 390.96 \mathrm{~b}$ \\
\hline & EMB & $0.93 \pm 0.15 \mathrm{bc}$ & $0.31 \pm 0.04 \mathrm{bc}$ & $0.31 \pm 0.04 \mathrm{bc}$ & $0.11 \pm 0.02 \mathrm{~b}$ & $0.57 \pm 0.08 \mathrm{c}$ & $0.14 \pm 0.05 \mathrm{c}$ & $168.72 \pm 109.64 \mathrm{~b}$ \\
\hline & LMB & $1.05 \pm 0.32 \mathrm{bc}$ & $0.27 \pm 0.07 \mathrm{bc}$ & $0.26 \pm 0.07 \mathrm{bc}$ & $0.09 \pm 0.06 \mathrm{~b}$ & $0.48 \pm 0.13 \mathrm{c}$ & $0.31 \pm 0.26 \mathrm{c}$ & $3603.71 \pm 2192.01 \mathrm{a}$ \\
\hline \multirow[t]{4}{*}{$-6 \mathrm{~cm}$} & $\mathrm{BL}$ & $1.36 \pm 0.26 \mathrm{bc}$ & $0.72 \pm 0.19 \mathrm{a}$ & $0.69 \pm 0.16 \mathrm{a}$ & $0.61 \pm 0.34 \mathrm{~b}$ & $2.30 \pm 0.52 \mathrm{a}$ & $3.89 \pm 3.01 \mathrm{bc}$ & $108.74 \pm 95.49 \mathrm{~b}$ \\
\hline & LB & $0.99 \pm 0.37 \mathrm{bc}$ & $0.33 \pm 0.07 \mathrm{~b}$ & $0.32 \pm 0.07 \mathrm{~b}$ & $0.25 \pm 0.04 \mathrm{~b}$ & $1.07 \pm 0.23 \mathrm{bc}$ & $0.85 \pm 0.19 \mathrm{c}$ & $12.18 \pm 4.02 \mathrm{~b}$ \\
\hline & EMB & $0.49 \pm 0.16 \mathrm{c}$ & $0.23 \pm 0.06 \mathrm{bc}$ & $0.24 \pm 0.06 \mathrm{bc}$ & $0.07 \pm 0.02 \mathrm{~b}$ & $0.79 \pm 0.19 \mathrm{c}$ & $0.13 \pm 0.08 \mathrm{c}$ & $1667.40 \pm 1192.36 \mathrm{ab}$ \\
\hline & LMB & $0.49 \pm 0.13 \mathrm{c}$ & $0.18 \pm 0.05 \mathrm{bc}$ & $0.19 \pm 0.06 \mathrm{bc}$ & $0.12 \pm 0.04 \mathrm{~b}$ & $0.64 \pm 0.20 \mathrm{c}$ & $0.35 \pm 0.14 \mathrm{c}$ & $187.57 \pm 162.26 \mathrm{~b}$ \\
\hline \multirow[t]{4}{*}{$-12 \mathrm{~cm}$} & BL & $2.95 \pm 0.70 \mathrm{a}$ & $0.20 \pm 0.05 \mathrm{bc}$ & $0.12 \pm 0.02 \mathrm{c}$ & $1.20 \pm 0.29 \mathrm{a}$ & $1.32 \pm 0.19 \mathrm{bc}$ & $63.96 \pm 26.20 \mathrm{a}$ & $0.47 \pm 0.25 \mathrm{~b}$ \\
\hline & LB & $1.61 \pm 0.47 \mathrm{~b}$ & $0.11 \pm 0.03 \mathrm{c}$ & $0.08 \pm 0.02 \mathrm{c}$ & $0.69 \pm 0.19 \mathrm{ab}$ & $0.91 \pm 0.18 \mathrm{bc}$ & $25.63 \pm 11.06 \mathrm{~b}$ & $0.55 \pm 0.19 \mathrm{~b}$ \\
\hline & EMB & $0.79 \pm 0.26 \mathrm{bc}$ & $0.05 \pm 0.02 \mathrm{c}$ & $0.05 \pm 0.01 \mathrm{c}$ & $0.32 \pm 0.10 \mathrm{~b}$ & $0.53 \pm 0.15 \mathrm{c}$ & $7.27 \pm 3.30 \mathrm{bc}$ & $1.78 \pm 0.51 \mathrm{~b}$ \\
\hline & LMB & $0.91 \pm 0.29 \mathrm{bc}$ & $0.06 \pm 0.02 \mathrm{c}$ & $0.05 \pm 0.01 \mathrm{c}$ & $0.37 \pm 0.12 \mathrm{~b}$ & $0.57 \pm 0.16 \mathrm{c}$ & $12.40 \pm 5.96 \mathrm{bc}$ & $1.80 \pm 0.73 \mathrm{~b}$ \\
\hline
\end{tabular}

Note. ${ }^{\dagger}$ Different letters in the same column indicate significant differences at the probability level of 0.05 . BL: bare land with sporadic cyanobacteria biocrusts; LB: lichen-dominated biocrusts; EMB: early-successional moss biocrusts; LMB: late-successional moss biocrusts. 

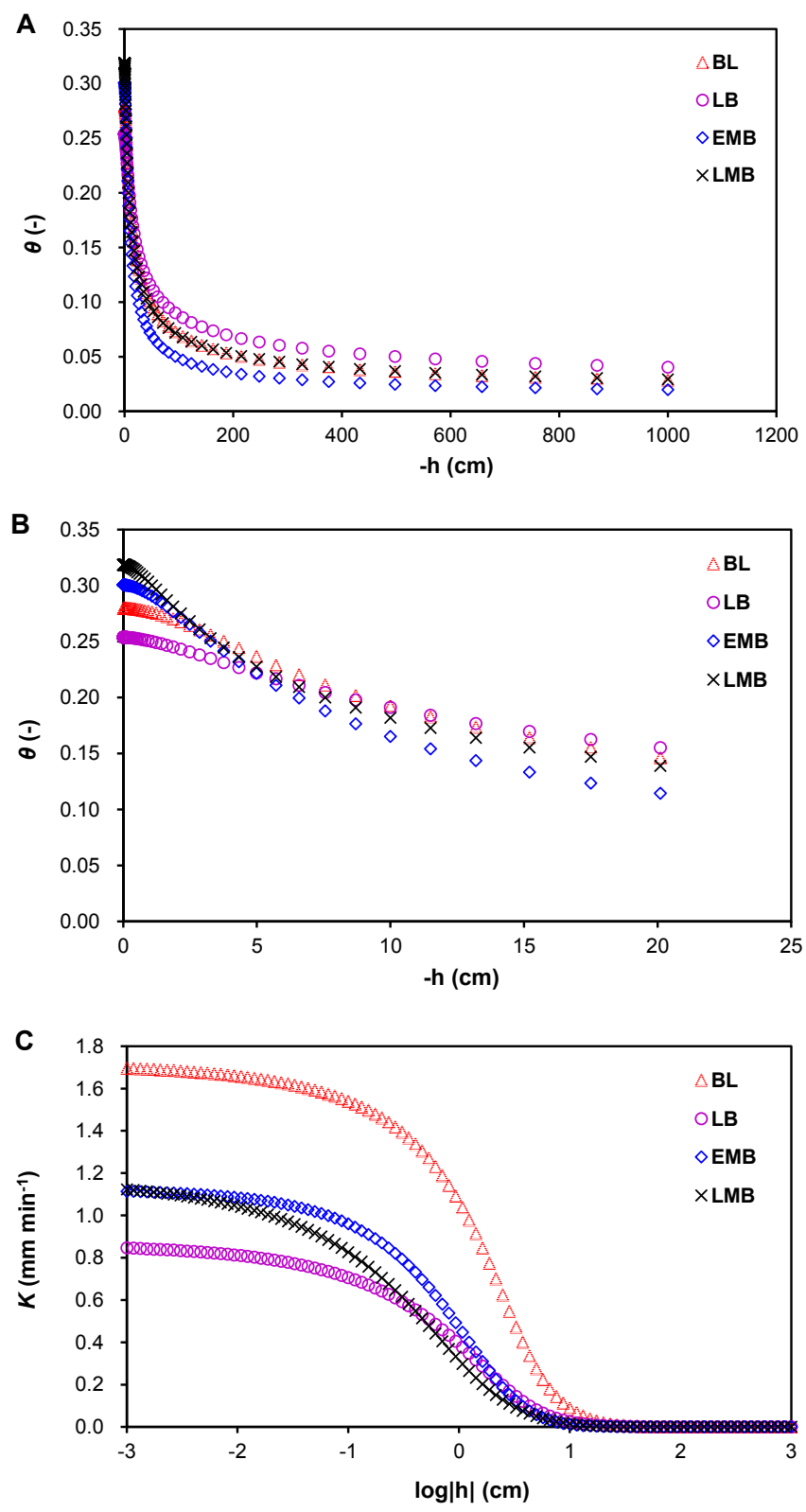

Fig. 3. Water retention (A and B) and hydraulic conductivity (C) of the four treatments including bare land with sporadic cyanobacterial biocrusts (BL), lichen-dominated biocrusts (LB), earlysuccessional moss biocrusts (EMB), and late-successional moss biocrusts (LMB).

polysaccharide content for the moss-covered biocrusts could explain this phenomenon (Table 1; Kidron et al., 2003; Chamizo et al., 2012). Furthermore, higher fine content (i.e., silt and clay) in the moss-covered biocrusts may reduce soil infiltrabil- ity when compared to the lichen-covered biocrusts (Table 1; Xiao et al., 2019). Similarly, Wu et al. (2012) concluded that soil infiltrability was lower for the moss-covered biocrusts compared to the lichen-covered biocrusts. On the contrary, some other studies have found that infiltration increased when biocrusts shifted from cyanobacteria or algae to lichens or mosses, which is usually characterized by increased biomass (Barger et al., 2006; Chamizo et al., 2012). The different response of infiltration to biocrust type was dependent upon surface roughness. In these regions, greater roughness which may have been caused by frost-heaving for lichen- or mossdominated biocrusts than those for the cyanobacteria or algae could explain the contradictory results (Belnap et al., 2013).

It should be noted that the use of a disc infiltrometer does not adequately reflect water flow under natural conditions. Firstly, it does not reflect surface roughness, because a layer of fine sand was laid on soil surface before infiltration experiments were performed. Therefore, the use of a disc infiltrometer could alleviate the influence of surface roughness caused by biocrusts on water infiltration. Secondly, unlike onedimensional vertical flow under natural conditions, the unconfined three-dimensional infiltration (vertical and lateral flow) usually take place under tension condition when using a disc infiltrometer (Vandervaere et al., 1997). Although there are some above-mentioned limitations, the disc infiltrometer under tension condition can still reflect biocrust effect on soil infiltrability, as verified by a similar study of Xiao et al. (2019) that reported consistent results of the double-ring infiltrometer and the disc infiltrometer. Considering the above-mentioned issues, further research is needed to evaluate the difference between the double-ring infiltrometer and disc infiltrometer in our study site.

\subsection{Determination of van Genuchten parameters}

Parametrization of hydraulic properties on biocrusted soils and estimation of soil hydraulic parameters are crucial for improving simulation of infiltration and soil water dynamics in vegetation-soil-water models (Coppola et al., 2011; Yu et al., 2010), and thus the understanding of eco-hydrological processes in dryland ecosystems (Rodríguez-Caballero et al., 2015). Among them, the most important factor is to estimate the parameters of van Genuchten model. Our results indicated that moss-covered soils had lower $K_{\mathrm{s}}$ than lichen-covered soils; however, the $\theta_{\mathrm{s}}$ for the moss-covered soils was higher than that for lichen-covered soils, although the differences were insignificant. This result could be attributed to the higher fine content and polysaccharide content of the moss-covered soils when compared to lichen-covered soils (Table 1). Furthermore, similar to our simulation study, the results of field experiments by Guan and Liu (2019) also found that well-developed mosscovered biocrusts had higher $\theta_{\mathrm{s}}$ than lichen-covered biocrusts, suggesting a higher retention capacity for the moss-covered biocrusts.

Table 3. $P$ values from the two-way ANOVA to test the influences of biocrust type and pressure head as well as their interaction effects on soil hydraulic parameters.

\begin{tabular}{lccccccc}
\hline Effects & $i_{\text {ini }}\left(\mathrm{mm} \mathrm{min}^{-1}\right)$ & $i_{\mathrm{c}}\left(\mathrm{mm} \mathrm{min}^{-1}\right)$ & $S\left(\mathrm{~mm} \mathrm{~min}^{-1 / 2}\right)$ & $\left.K(h)(\mathrm{mm} \mathrm{min})^{-1}\right)$ & $K_{\mathrm{s}}\left(\mathrm{mm} \mathrm{min}^{-1}\right)$ & $\lambda_{\mathrm{c}}(\mathrm{mm})$ & $\lambda_{\mathrm{m}}(\mathrm{mm})$ \\
\hline Biocrusts & $0.001^{* *}$ & $<0.001^{* *}$ & $<0.001^{* *}$ & $<0.001^{* *}$ & $<0.001^{* *}$ & $0.013^{*}$ & 0.175 \\
\hline Pressure head & $0.015^{*}$ & $<0.001^{* *}$ & $<0.001^{* *}$ & $0.024^{*}$ & $0.023^{*}$ & $<0.001^{* *}$ & 0.133 \\
\hline Biocrusts $\times$ Pressure head & 0.188 & 0.149 & $0.020^{*}$ & 0.431 & 0.949 & $0.031^{*}$ & $0.040^{*}$
\end{tabular}

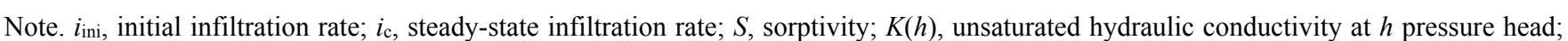
$K_{\mathrm{s}}$, saturated hydraulic conductivity; $\lambda_{\mathrm{c}}$, macroscopic capillary length; $\lambda_{\mathrm{m}}$, microscopic pore radius. ${ }^{*}$ Effect is significant at .05 level of probability. ${ }^{* *}$ Effect is significant at .01 level of probability. 
Table 4. Water retention and hydraulic conductivity parameters for the biocrusted soils under the different biocrust development.

\begin{tabular}{lccc}
\hline Treatments & $\theta_{\mathrm{s}}$ & $\alpha_{\mathrm{VG}}\left(\mathrm{cm}^{-1}\right)$ & $n$ \\
\hline Bare land with sporadic cyanobacterial biocrusts (BL) & $0.28 \pm 0.02 \mathrm{a}^{\dagger}$ & $0.11 \pm 0.03 \mathrm{a}$ & $1.72 \pm 0.14 \mathrm{a}$ \\
\hline Lichen-dominated biocrusts (LB) & $0.25 \pm 0.01 \mathrm{a}$ & $0.12 \pm 0.03 \mathrm{a}$ & $1.51 \pm 0.07 \mathrm{a}$ \\
\hline Early-successional moss biocrusts (EMB) & $0.30 \pm 0.02 \mathrm{a}$ & $0.21 \pm 0.04 \mathrm{a}$ & $1.72 \pm 0.08 \mathrm{a}$ \\
\hline Late-successional moss biocrusts (LMB) & $0.32 \pm 0.04 \mathrm{a}$ & $0.27 \pm 0.09 \mathrm{a}$ & $1.54 \pm 0.07 \mathrm{a}$ \\
\hline
\end{tabular}

${ }^{\dagger}$ Different letters in the same column indicate significant differences at the probability level of 0.05 .

Table 5. Regional difference in the biocrust effects on soil water infiltrability (in increasing order of annual precipitation).

\begin{tabular}{|c|c|c|c|c|c|c|}
\hline Locations & $\begin{array}{l}\text { Climate (annual } \\
\text { precipitation in } \mathbf{m m} \text { ) }\end{array}$ & Soil texture & Biocrust type & $\begin{array}{l}\text { Measured } \\
\text { parameters }\end{array}$ & $\begin{array}{l}\text { Biocrust effects } \\
\text { on infiltration }\end{array}$ & References \\
\hline $\begin{array}{l}\text { Heihe River } \\
\text { Basin }\end{array}$ & Hyper arid (71) & Silty loam & & Infiltration rate & Decreasing & Yang et al. (2016) \\
\hline $\begin{array}{l}\text { Central-Western } \\
\text { Negev Desert }\end{array}$ & Hyper arid (90) & Sand & Cyanobacteria & Infiltration rate & $\begin{array}{l}\text { Increasing under } \\
\text { tension; no signifi- } \\
\text { cant effect under } \\
\text { ponding }\end{array}$ & $\begin{array}{l}\text { Eldridge et al. } \\
(2000)\end{array}$ \\
\hline $\begin{array}{l}\text { Western Negev } \\
\text { Desert }\end{array}$ & Hyper arid (95) & Sand & Cyanobacteria & Runoff yield & Decreasing & Kidron (2016) \\
\hline Mojave Desert & Arid (101) & Sand; loamy sand & Cyanobacteria & Infiltration rate & Decreasing & Herrick et al. (2010) \\
\hline Tengger Desert & Arid (191) & Sand & Mosses & Infiltration rate & Increasing & $\begin{array}{l}\text { Coppola et al. } \\
\text { (2011) }\end{array}$ \\
\hline Tabernas Desert & Semiarid (200-235) & $\begin{array}{l}\text { Silty loam; sandy } \\
\text { loam }\end{array}$ & $\begin{array}{l}\text { Cyanobacteria; } \\
\text { lichens; mosses }\end{array}$ & Infiltration rate & $\begin{array}{l}\text { Decreasing with } \\
\text { biocrust develop- } \\
\text { ment }\end{array}$ & $\begin{array}{l}\text { Chamizo et al. } \\
\text { (2012) }\end{array}$ \\
\hline Colorado Plateau & Semiarid (215) & Loamy sand & $\begin{array}{l}\text { Cyanobacteria; } \\
\text { cyanolichens }\end{array}$ & Runoff coefficient & Decreasing & Faist et al. (2017) \\
\hline $\begin{array}{l}\text { Southeastern } \\
\text { Spain }\end{array}$ & Semiarid (220-235) & $\begin{array}{l}\text { Silty loam; sandy } \\
\text { loam }\end{array}$ & Cyanobacteria & Runoff coefficient & $\begin{array}{l}\text { Decreasing with } \\
\text { biocrust develop- } \\
\text { ment }\end{array}$ & Cantón et al. (2020) \\
\hline $\begin{array}{l}\text { Western New } \\
\text { South Wales }\end{array}$ & Semiarid (244) & Sand & $\begin{array}{l}\text { Cyanobacteria; } \\
\text { lichens; mosses }\end{array}$ & Infiltration rate & Increasing & Bowker et al. (2013) \\
\hline $\begin{array}{l}\text { Northern Chihua- } \\
\text { huan Desert }\end{array}$ & Semiarid (250) & Sandy clay loam & Cyanobacteria & Infiltration depth & Increasing & Chung et al. (2019) \\
\hline $\begin{array}{l}\text { Quara Qir range- } \\
\text { lands }\end{array}$ & Semiarid (273) & Loamy & Lichens; mosses & Infiltration rate & Increasing & Kakeh et al. (2021) \\
\hline $\begin{array}{l}\text { Qinghai-Tibet } \\
\text { Plateau }\end{array}$ & Semiarid (389) & Silty loam & Mosses & Infiltration rate & Increasing & Jiang et al. (2018) \\
\hline Loess Plateau & Semiarid (409) & Loamy sand & $\begin{array}{l}\text { Cyanobacteria; } \\
\text { mosses }\end{array}$ & Infiltration rate & Decreasing & Xiao et al. (2019) \\
\hline
\end{tabular}

Additionally, our results indicated that the shape parameter of $\alpha_{\mathrm{VG}}$ followed the pattern LMB $>$ EMB $>$ LB $>$ BL. This result suggests that the shape parameters of $\alpha_{\mathrm{VG}}$ increased with biocrust development. A higher $\alpha_{\mathrm{VG}}$ corresponds to a lower air entry value, and implies a lower water holding capacity near saturation (van Genuchten, 1980). Moreover, this result indicates that the higher $\alpha_{\mathrm{VG}}$ was consistent with a higher content of clay and silt. On the contrary, Wang et al. (2007) reported that the shape parameter of $\alpha_{\mathrm{VG}}$ declined as the time since stabilization increased, and the lower $\alpha_{\mathrm{VG}}$ was related to a higher proportion of silt- and clay-sized particle. The difference in the inverse method and model uncertainty may lead to this discrepancy.

The development of biocrusts leads to different van Genuchten parameters, which alter the $\theta(h)$ and $K(h)$ curves. Our results indicate that $\theta(h)$ on the moss-covered soils was higher than on the lichen-covered soils at high-pressure heads; however, the opposite was observed at low-pressure heads (Fig. 3B). In addition, moss-covered soils had lower $K(h)$ than the lichencovered soils. Decrease in $K(h)$ and increase in $\theta(h)$ are likely due to the characteristics of biocrusts when compared to bare land. In comparison to the bare land, greater water-holding capacity on the biocrust-covered soils could lead to an improved water conditions on the soil surface (Fig. 3B; Guan and Liu, 2019). Furthermore, the anchoring structures on lichen- covered soils allows for a longer residence time of the water, which could improve water retention at the soil surface. Moreover, higher content of clay and silt in the moss-covered biocrusts reduce the soil pores, and lead to a decrease in soil hydraulic conductivity. Accordingly, the presence of lichen or moss biocrusts on the soil surface enhances water retention, but inhibits soil hydraulic conductivity.

The occurrence and development of biocrusts change van Genuchten parameters and affect the water retention curve, and subsequently alters the available water in the biocrust layer. We found that available water in the biocrust layer increased with a shift in biocrusts from cyanobacteria to lichens or mosses (Fig. $3 \mathrm{~A}$ and $\mathrm{B})$. It is noted that available water mentioned above focused on the soil surface (i.e., biocrust layer). The increased water content on the soil surface implies a lower soil water content of the shrub root layer. This suggests that the presence and development of biocrusts could facilitate the growth of annual plants, but inhibit the growth of vascular plants. Moreover, higher soil surface water content has important implications for dryland productivity. Therefore, our results provide strong support for the explicit inclusion of biocrusts in hydrological and ecohydrological models.

Our study focused on the effects of biocrust development on soil infiltrability. The presence and development of biocrusts 
change the water infiltration during rainfall events and alter soil evaporation during the drying periods, and consequently have the potential to influence plant water uptake, and eventually impact plant growth (Xiao and Hu, 2017; Zhang and Belnap, 2015; Zhuang et al., 2015). In addition, biocrusts are very fragile and are susceptible to disturbance, which could affect water infiltration during rainfall events (Barger et al., 2006; Chamizo et al., 2012). However, how the biocrust development and its disturbance influence soil water availability and shrub growth have not yet been well understood (Chamizo et al., 2016; Kidron and Aloni, 2018). Accordingly, further studies are necessary to evaluate the role of the biocrust development and its disturbance in soil water uptake and growth of vascular plants in drylands.

\section{CONCLUSIONS}

Infiltration rate decreases and saturated soil moisture increases with biocrust development, especially with the presence of moss biocrusts. Water retention increases with biocrust development at high-pressure head, whereas the opposite is found at low-pressure heads. The biocrust development influences van Genuchten parameters, subsequently affecting the water retention curve, and thereby altering the available water in the biocrust layer. The findings regarding the parameterization of soil hydraulic properties have important implications for the simulation of eco-hydrological processes in dryland ecosystems.

Acknowledgements. This study was funded by the Fundamental Research Funds for the Central Universities (BLX2013030).

Data availability statement. The data that support the findings of this study are available from the corresponding author upon reasonable request.

\section{REFERENCES}

Barger, N.N., Herrick, J.E., Van Zee, J., Belnap, J., 2006. Impacts of biological soil crust disturbance and composition on $\mathrm{C}$ and N loss from water erosion. Biogeochem., 77, 247-263.

Belnap, J., 2006. The potential roles of biological soil crusts in dryland hydrologic cycles. Hydrol. Process., 20, 3159-3178.

Belnap, J., Wilcox, B.P., Van Scoyoc, M.V., Phillips, S.L., 2013. Successional stage of biological soil crusts: an accurate indicator of ecohydrological condition. Ecohydrology, 6, 474-482.

Bowker, M.A., Eldridge, D.J, Val, J., Soliveres, S., 2013. Hydrology in a patterned landscape is co-engineered by soildisturbing animals and biological crusts. Soil Biol. Biochem., 61, 14-22.

Cantón, Y., Chamizo, S., Rodriguez-Caballero, E., Lázaro, R., Roncero-Ramos, B., Román, J.R., Solé-Benet, A., 2020. Water regulation in cyanobacterial biocrusts from drylands: Negative impacts of anthropogenic disturbance. Water, 12, 3, 720.

Chamizo, S., Cantón, Y., Lázaro, R., Solé-Benet, A., Domingo, F., 2012. Crust composition and disturbance drive infiltration through biological soil crusts in semi-arid ecosystems. Ecosystems, 15, 148-161.

Chamizo, S., Cantón, Y., Rodríguez-Caballero, E., Domingo, F., 2016. Biocrusts positively affect the soil water balance in semiarid ecosystems. Ecohydrology, 9, 1208-1221.

Chen, N., Wang, X., Zhang, Y., Yu, K., Zhao, C., 2018. Ecohydrological effects of biological soil crust on the vegetation dynamics of restoration in a dryland ecosystem. J. Hydrol., 563, 1068-1077.
Chenu, C., 1993. Clay- or sand-polysaccharide associations as models for the interface between micro-organisms and soil: water related properties and microstructure. Geoderma, 56, $143-156$.

Chung, Y.A., Thornton, B., Dettweiler-Robinson, E., Rudgers, J.A., 2019. Soil surface disturbance alters cyanobacterial biocrusts and soil properties in dry grassland and shrubland ecosystems. Plant soil, 441, 147-159.

Colica, G., Li, H., Rossi, F., Li, D., Liu, Y., De Philippis, R., 2014. Microbial secreted exopolysaccharides affect the hydrological behavior of induced biological soil crusts in desert sandy soils. Soil Biol. Biochem., 68, 62-70.

Coppola, A., Basile, A., Wang, X., Comegna, V., Tedeschi, A., Mele, G., Comegna, A., 2011. Hydrological behaviour of microbiotic crusts on sand dunes: Example from NW China comparing infiltration in crusted and crust-removed soil. Soil Till. Res., 117, 34-43.

Eldridge, D.J., Zaady, E., Shachak, M., 2000. Infiltration through three contrasting biological soil crusts in patterned landscapes in the Negev, Israel. Catena, 40, 323-336.

Eldridge, D.J., Reed, S., Travers, S.K., et al. 2020. The pervasive and multifaceted influence of biocrusts on water in the world's drylands. Glob. Change Biol., 26, 10, 6003-6014.

Faist, A.M., Herrick, J.E., Belnap, J., Van Zee, J.W., Barger, N.N., 2017. Biological soil crust and disturbance controls on surface hydrology in a semi-arid ecosystem. Ecosphere, 8, e01691.

Felde, V.J.M.N.L., Peth, S., Uteau-Puschmann, D., Drahorad, S., Felix-Henningsen, P., 2014. Soil microstructure as an under-explored feature of biological soil crust hydrological properties: Case study from the NW Negev Desert. Biodivers. Conserv., 64, 133-140.

Gardner, W.R., 1958. Some steady-state solutions of the unsaturated moisture flow equation with application to evaporation from a water table. Soil Sci., 85, 4, 228-232.

Gentili, F., Nilsson, M.C., Zackrisson, O., DeLuca, T.H., Sellstedt, A., 2005. Physiological and molecular diversity of feather moss associative $\mathrm{N}_{2}$-fixing cyanobacteria. J. Exp. Bot., 56, 422, 3121-3127.

Guan, H.J., Liu, X.Y., 2019. Does biocrust successional stage determine the degradation of vascular vegetation via alterations in its hydrological roles in semi-arid ecosystem? Ecohydrology, 12, e2075.

Havrilla, C.A., Chaudhary, V.B., Ferrenberg, S., Antoninka, A.J., Belnap, J., Bowker, M.A., ... Barger, N.N., 2019. Towards a predictive framework for biocrust mediation of plant performance: A meta-analysis. J. Ecol., 107, 6, 2789-2807.

Herrick, J.E., Van Zee, J.W., Belnap, J., Johansen, J.R., Remmenga, M., 2010. Fine gravel controls hydrologic and erodibility responses to trampling disturbance for coarse-textured soils with weak cyanobacterial crusts. Catena, 83, 119-126.

Jiang, Z.Y., Li, X.Y., Wei, J.Q., Chen, H.Y., Li, Z.C., Liu, L., $\mathrm{Hu}, \mathrm{X}$., 2018. Contrasting surface soil hydrology regulated by biological and physical soil crusts for patchy grass in the highaltitude alpine steppe ecosystem. Geoderma, 326, 201-209.

Kakeh, J., Gorji, M., Mohammadi, M.H., Asadi, H., Khormali, F., Sohrabi, M., Eldridge, D.J., 2021. Biocrust islands enhance infiltration, and reduce runoff and sediment yield on a heavily salinized dryland soil. Geoderma, 404, 3, 115329.

Keck, H., Felde, V.J.M.N.L., Drahorad, S.L., FelixHenningsen, P., 2016. Biological soil crusts cause subcritical water repellency in a sand dune ecosystem located along a rainfall gradient in the NW Negev desert, Israel. J. Hydrol. Hydromech., 64, 133-140.

Kidron, G.J., 2016. Goat trampling affects plant establishment, 
runoff and sediment yields over crusted dunes. Hydrol. Process., 30, 2237-2246.

Kidron, G.J., 2019. The dual effect of sand-covered biocrusts on annual plants: Increasing cover but reducing individual plant biomass and fecundity. Catena, 182, 104120.

Kidron, G.J., Aloni, I., 2018. The contrasting effect of biocrusts on shallow-rooted perennial plants (hemicryptophytes): Increasing mortality (through evaporation) or survival (through runoff). Ecohydrology, 11, e1912.

Kidron, G.J., Yair, A., Vonshak, A., Abeliovich, A., 2003. Microbiotic crust control of runoff generation on sand dunes in the Negev Desert. Water Resour. Res., 39, 1108.

Kidron, G.J., Wang, Y., Herzberg, M., 2020. Exopolysaccharides may increase biocrust rigidity and induce runoff generation. J. Hydrol., 588, 125081.

Lazarowitch, N., Ben-Gal, A., Šimůnek, J., Shani, U., 2007. Uniqueness of soil hydraulic parameters determined by a combined Wooding inverse approach. Soil Sci. Soc. Am. J., $71,860-865$.

Ludwig, J., Wilcox, B., Breshears, D., Tongway, D., Imeson, A., 2005. Vegetation patches and runoff-erosion as interacting ecohydrological processes in semiarid landscapes, Ecology, 86, 2, 288-297.

Mazor, G., Kidron, G.J., Vonshak, A., Abeliovich, A., 1996. The role of cyanobacterial exopolysaccharides in structuring desert microbial crusts. FEMS Microbiol. Ecol., 21, 121-130.

Mualem, Y., 1976. A new model for predicting the hydraulic conductivity of unsaturated porous media. Water Resour. Res., 12, 513-522.

Paulsrud, P., Lindblad, P., 1998. Sequence variation of the

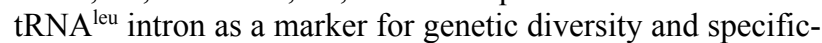
ity of symbiotic cyanobacteria in some lichens. Appl. Environ. Microb., 64, 310-315.

Rodriguez-Caballero, E., Cantón, Y., Jetten, V., 2015. Biological soil crust effects must be included to accurately model infiltration and erosion in drylands: An example from Tabernas Badlands. Geomorphology, 241, 331-342.

Rossi, F., Mugnai, G., De Philippis, R., 2018. Complex role of the polymeric matrix in biological soil crusts. Plant Soil, 429, 19-34.

Šimůnek, J., van Genuchten, M.Th., 2000. The DISC Computer Software for Analyzing Tension Disc Infiltrometer Data by Parameter Estimation, Version 1.0, Research Report No. 145. U.S. Salinity Laboratory, USDA, ARS, Riverside, California.

Smettem, K.R.J, Clothier, B.E., 1989. Measuring unsaturated sorptivity and hydraulic conductivity using multiple disc permeameters. J. Soil Sci., 40, 563-568.

van Genuchten, M.Th., 1980. A closed-form equation for predicting the hydraulic conductivity of unsaturated soils. Soil Sci. Soc. Am. J., 44, 892-898.

Vandervaere, J.P., Peugeot, C., Vauclin, M., Angulo Jaramillo, R., Lebel, T., 1997. Estimating hydraulic conductivity of crusted soils using disc infiltrometers and minitensiometers. J. Hydrol., 188-189, 203-223.

Wang, X.P., Young, M.H, Yu, Z., Li, X.R, Zhang, Z.S., 2007. Long-term effects of restoration on soil hydraulic properties in revegetation-stabilized desert ecosystems. Geophys. Res. Lett., 34, L24S22.

Warren, S.D., 2003. Synopsis: influence of biological soil crusts on arid land hydrology and soil stability. In: Belnap, J., Lange, O.L. (Eds.): Biological Soil Crusts: Structure, Function, and Management, vol 150, Ecological Studies. Springer, Berlin, pp. 349-360.

Warrick, A.W., 1992. Models for disc infiltrometer. Water Resour. Res., 28, 1319-1327.

Weber, B., Büdel, B., Belnap, J., 2016. The role of biocrusts in arid land hydrology. In: Chamizo, S., Belnap, J., Eldridge, D.J., Cantón, Y., Issa, O.M. (Eds.): Biological Soil Crusts: An Organizing Principle in Drylands. Ecological Studies. Springer, Berlin, pp. 321-326.

White, I., Sully, M.J., 1987. Macroscopic and microscopic capillary length and time scales from field infiltration. Water Resour. Res., 23, 1514-1522.

Wooding, RA., 1968. Steady infiltration from a shallow circular pond. Water Resour. Res., 4, 4, 1259-1273.

Wu, Y.S., Hasi, E., Wugetemole, Wu, X., 2012. Characteristics of surface runoff in a sandy area in southern Mu Us sandy land. Chinese Sci. Bull., 57, 2-3, 270-275.

Xiao, B, Hu, K.L., 2017. Moss-dominated biocrusts decrease soil moisture and result in the degradation of artificially planted shrubs under semiarid climate. Geoderma, 291, 47-54.

Xiao, B., Sun, F.H, Hu, K.L, Kidron, G.J., 2019. Biocrusts reduce surface soil infiltrability and impede soil water infiltration under tension and ponding conditions in dryland ecosystem. J. Hydrol., 568, 792-802.

Yang, J.L., Zhang, G.L., Yang, F., Yang, R.M., Yi, C., Li, D.C., Zhao, Y.G., Liu, F., 2016. Controlling effects of surface crusts on water infiltration in an arid desert area of Northwest China. J. Soils Sediment., 16, 2408-2418.

Yu, Z., Lü, H., Zhu, Y., Drake, S., Liang, C., 2010. Long-term effects of revegetation on soil hydrological processes in vegetation-stabilized desert ecosystems. Hydrol. Process., 24, 87-95.

Zhang, Y.M., Belnap, J., 2015. Growth responses of five desert plants as influenced by biological soil crusts from a temperate desert. Ecol. Res., 30, 1037-1045.

Zhuang, W.W., Serpe, M., Zhang, Y.M., 2015. The effect of lichen-dominated biological soil crusts on growth and physiological characteristics of three plant species in a temperate desert of northwest China. Plant Biol., 17, 11651175.

Received 28 June 2021 Accepted 18 August 2021 